\title{
Developing A Creative Economic-Based Village Tourism In Kendran Village Gianyar Regency
}

\author{
Diploma IV Tourism Study Program \\ Faculty of ATourism-Udayana University \\ Denpasar \\ arismayanti_pariwisata@yahoo.co.id \\ Tourism Study Program \\ Faculty of ATourism-Udayana University \\ Denpasar \\ Agribusiness Study Program \\ Faculty of Agriculture -Udayana University \\ Denpasar
}

Ni Ketut Arismayanti ${ }^{1}$, I Gusti Ngurah Widyatmaja ${ }^{2}$, I Wayan Wiraatmaja ${ }^{3}$

\begin{abstract}
This research aims to identify the potential of natural tourism, cultural tourism, and creativity of local communities of Kendran Village and determine the condition of the internal environment (as seen from the strengths and weaknesses) and external environment (as seen from the opportunities and threats) of Kendran Village since the development of creative-economy based village tourism is one of the attempts to open up the market share (market niche) that had not been done yet. SWOT analysis method was used in this research to explore the potential of the internal environment, such as Strengths, namely rice field scenery with jogging tracks, the preserved traditional culture as traditional Balinese architecture, sacred places, historical relics in the village area, the activities of the Balinese-Hinduism ceremonies, arts and cultures, as well as the hospitality of communities, and accessible areas. We found the weaknesses on infrastructure, public facilities, lack of tourism programs along with its management, and lack of foreign languages including English. Likewise, on the external environment, they have the opportunities in location of Kendran Village, the popularity of village tourism, increasing of tourists arrival who are interested in culture \& natural tourism, information and technological advances that support the promotion of Kendran Village, the support of the Gianyar Government, the development of creative-economy based tourism, and the threats such as increased competition in tourism industry, lack of passion of rural life in young generations, the culture commercialization, and also the stability of political and security situation in Indonesia.
\end{abstract}

Index Terms - natural potentials, cultural potentials, creative local community, creative economy.

\section{INTRODUCTION}

The government through the Ministry of Culture and Tourism is currently aggressively developing tourism villages throughout Indonesia through the National Program of Community Empowerment on Tourism, called PNPM Mandiri. It is trying to help people who live in near by tourism destinations, especially those having potential for tourism development activities, closed to the Object of
Tourism Destination (ODTW), and tourism support facilities (budpar, 2010).

Kendran Village is one of the villages in Gianyar Regency which has the potential for developing a creative economybased tourism village. It is suitable to be developed as a tourism village because: 1) it is very strategic (closed to tourist area of Ubud); 2) it has local genius and religious tradition which is strongly maintained; 3) local people are very creative in fields of art carving and sculpture of the local products developed as a souvenir for tourists. In addition, it is famous for its thousands of art shops.

The development of tourism village in Kendran Village is 
therefore ideally based upon a high selling value to be a leading tourist attraction. Unfortunately, it has not been able to be developed and managed as a professional tourism village by such aspects as management, human resources, and utilization of its potential. For this reason, this research is very important to do, so the development of Kendran Village as a tourism village based on creative economy can be used as a model of development of other tourist villages in Bali.

\section{REVIEW OF LITERATURE}

\section{A. Creative Economy Concept}

The creative economy is a concept in the new economic era that intensifies information and creativity by relying on the idea and stock of knowledge from Human Resources as the main factor of production in its economic activity. The structure of the world economy is undergoing rapid transformation in line with economic growth, from the natural resources to human resources, from the agricultural era to the industrial era and information

Until now the creative economy cannot be clearly defined. Creativity, which is a vital element in the creative economy, is still difficult to distinguish whether as a process or innate human character. The Ministry of Trade of Republic of Indonesia formulates creative economy as a sustainable economic development effort through creativity with a competitive economic climate and reserves of renewable resources. A clearer definition is given by UNDP that creative economy is an integrative part of innovative knowledge, creative use of technology, and culture. This can be explained in the chart as shown in Figure 2.1 below.

The scope of activities of the creative economy can cover many aspects. Ministry of Trade identified at least 14 sectors included in the creative economy, namely: 1. Advertisement; 2. Architecture; 3. Market of art goods; 4. Handicraft; 5. Design; 6. Fashion; 7. Film, video, and photography; 8. Interactive games; 9. Music; 10. Performing Arts; 11. Publishing and printing; 12. Computer and software services; 13. Radio and television; 14. Research and development

\section{B. The Creative Economy and Tourism Development}

The creative economy and tourism sector are two mutually influential things and can be synergized if managed well [1]. The concept of tourism activity can be defined by three factors; there must be something to see, something to do, and something to buy [2]. Something to see is related to attractions in a tourist destination, something to do is related to tourist activity in a tourist area, while something to buy is linked to typical souvenirs purchased in tourist areas as personal memory of tourists. Within the three components, the creative economy can enter through something to buy by creating innovative local products.

In the development of creative economy through the tourism sector described further by Yozcu and İçöz [3] that creativity will stimulate tourist destinations to create innovative products that will add value and higher competitiveness compared to other tourist destinations. Tourists in one hand will feel more interested to visit the tourist area that has a typical product to then take home as a souvenir. On the other hand, these creative products will indirectly involve individual and enterprise entrepreneurs in touch with the cultural sector. These contacts will have a positive impact on cultural preservation and at the same time improving the economy and the aesthetics of tourist sites.

The tourism potential can be developed through creative economy that does not only involve society or community as a quality resource, but also the element of bureaucracy with the pattern of entrepreneurship. The concept of bureaucratic engagement in the creative economy is that bureaucracy does not only spend but generates (income generating) in a positive sense [4]. Further Barringer [4] revealed that the strategy of developing the creative economy as a driver of the tourism sector is formulated as follows:

a. Increasing the role of art and culture of tourism

b. Strengthening the existence of creative industry clusters

c. Preparing creative human resources

d. Mapping assets that can support the emergence of a creative economy.

e. Developing a regional approach, which builds networks among creative industry clusters?

f. identifying leadership to maintain the sustainability of the creative economy by involving elements of bureaucracy as part of the leadership and facilitator.

g. Building and expanding networks across sectors

h. Developing and implementing strategies, including socializing policies related to the development of creative economy and tourism development to craftsmen. The craftsman should know whether there is an incentive for the development of the creative economy, or the export tax if necessary.

\section{Model of Creative Economy as Driver for Tourism Sector}

The development of the creative economy as a driver of the tourism sector requires synergy among stakeholders involved in it, namely government, intellectuals, and private sector (business). The model of creative economy development as a driving force for the tourism sector can be adapted from creative village or urban models. Creative villages or cities rely on the quality of human resources to shape (can be in the form of design or redesign) of creative spaces. The formation of creative space is needed to stimulate the emergence of creative ideas, because people who are placed in a good environment will be able to produce creative products of economic value. Cultural festival is one form of the creative space creations that successfully bring tourists. Further explanation is found in Chart Model of Synergy Creative Economy Stakeholders of Craft Sub-Sector can be seen in Figure 2.2 below. 


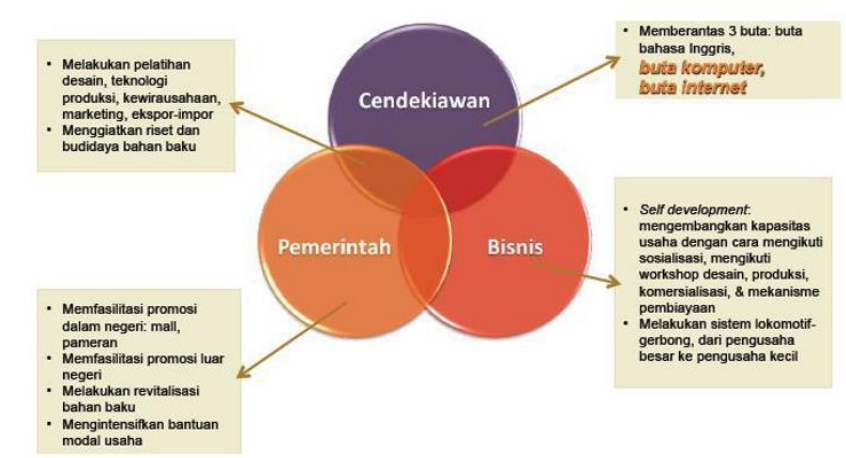

Fig. 1. Chart of the Synergy Model of Sub-Sector Creative Economy Stakeholders Handicraft (source: Ministry of Trade of Republic of Indonesia)

In the context of tourism, creative spaces are needed for the craftsmen to produce typical products of tourist areas that can not be found in other areas. One of the most important places is a workshop or studio. Workshops or studios as a creative space should be connected with the tourist area so as to create linkage or connectivity. Such connectivity is necessary to facilitate the production chain [5]. In terms of creative economy, handicraft products in the form of souvenirs can be sold while from the tourism sector tourists get a impressed with the tourist area. Connectivity or linkage between the creative economy and the tour can take the form of a sales outlet located in a tourist area. In other words, tourism becomes a venue for the creative economy for production, distribution, and marketing. Another thing that needs to be considered in the implementation of the linkage model is the determination of the location of outlets that must be cultivated in a strategic place and close to tourist attractions

\section{Community Empowerment}

Community participation is necessary in the implementation of sustainable development. Tourism development that does not involve the community often results in a sense of marginalization among the local community. The further consequence is a confrontation between the local community and the industry, which ultimately threatens the sustainability of tourism development itself.

To be able to increase community participation, it is indispensable that the development programs or innovations developed contain the following elements:

a. Giving the relative benefits, economically affordable and economically considered that the cost is less than the relative advantage.

b. Elements of innovation are considered not incompatible with local values and beliefs (compatibility).

c. newly communicated ideas and practices can be easily understood and practiced (complexity and practicability).

$\mathrm{d}$. The element of innovation is easily observed through demonstration or observability

Community participation is a must in every development, so that development can be sustainable. This is particularly true of multidimensional development. Woodly [6] stated that local people participation is a prerequisite for sustainable tourism".

In the concept of empowerment there are three components that must exist, namely:

a. Enabling setting, ie strengthening the situation of local level conditions to be good, so that local people can be creative

b. Empowering local community, meaning that after local setting is prepared, the knowledge and skill of local community should be enhanced so that they are able to use the setting well. This is done, among others, through education, training, and various other forms of human resource development.

c. Socio-political support, namely the need for social support, political support, networking, and so forth.

Although acknowledging that there are many positive things on large-scale development, and there are some weaknesses of small-scale development, many experts suggest that tourism development is small-scale tourism. Because only on a small scale community participation can be improved.

\section{E. Tourism Village Development}

The tourist village is a rural area that offers a whole atmosphere that reflects the authenticity of the countryside, in terms of its cultural social life, its daily customs, the architecture of the building and the spatial structure of the village, and has the potential to develop various components of tourism such as attractions, souvenirs, and other tourist needs. Edward Inskeep [6] stated that Village Tourism, where small groups of tourists stay in or near traditional atmosphere, often in remote villages and learn about village life and the local environment.

The development of tourist villages should be carefully planned so that the impacts can be controlled. In principle in the development of tourist villages should consider the following aspects:

a. Development of tourism facilities on a small scale and services within or near the village.

b. The facilities and services are owned and worked by the villagers through cooperation or individuals.

c. The development of a tourist village is based on one of the "Properties" of traditional culture that is close to nature with the development of the village as a service center for tourists visiting the attraction.

\section{RESEARCH METHODS}

This was a research done with qualitative and quantitative approaches of which the techniques of collecting data were direct observation, depth interview, and questionnaire. The result of data analysis could be formally (in the form of table) and informally (in narrative form) presented. The tool used to construct strategic factors was the SWOT (Strengths Weaknesses Opportunities Threats) matrix.

\section{A. Operational Definition of Variables}

To limit this study, the internal and external variables were used. Internal variables are factors of strengths and 
weakness of tourism potential of Kendran Village. The internal environmental variables identified are tourism potential, tourism objects and attractions, accessibility, tourism facilities, and human resources. While external variables are external factors in the form of opportunities and threats tourism potential of Kendran Village. The external environmental variables identified are economic, socio-cultural, government policy, security, politics, and technology.

\section{B. Data analysis}

Several methods of data analysis were used, namely: 1) Analysis of IFAS and EFAS matrix resulted in a grand strategy; 2) SWOT analysis using diagrams to generate alternative strategies; 3) QSPM analysis produced sequence of strategies ranging from the most priority to not priority. As for each method of analysis can be explained as follows:

\section{Analysis of IFAS and EFAS Matrices}

Analysis of IFAS matrix (Internal Strategic Factors Analysis Summary) and EFAS (External Strategic Factors Analysis Summary) was done to know how big influence of internal and external factors analyzed to condition of tourist village which must be managed. From the total value of internal and external factors, then plotting on an internalexternal matrix is a Nine cell diagram [7].

\section{DISCUSSION}

Kendran Village which is located in Tegallalang District, Gianyar Regency is a village that has natural, cultural, spiritual potentials and creativity of the community that can be managed and developed to support the village of Kendran as a creative economy -based tourist. This village is at the crossroads of several tourist attractions visited by many tourists, such as Ubud, Tampak Siring, Goa Gajah, and others. The potentials in Kendran Village in supporting a creative economy-based tourist village are:

\section{A. Potential of KendranVillage}

\section{a. Potental of Natural Tourist}

Kendran village has an unspoiled atmosphere with natural landscape of rice fields stretching wide and hilly views. This is the main attraction of this village. According to observations and interviews with Mr. Eka Suparta, tourist attractions that can be offered to tourists can be those of rice tracking, cycling tour, and seightseeing. Rice tracking is an activity along the village rice field. Tourists can do jogging or walking along the rice fields maturation. Then cycling tour is a cycling activity around the area in Kendran Village. Kenderan Village has created a cycling path for off road. Unfortunately, the location is still undetermined and still needs to be surveyed for suitable locations. Besides, it is planed to have bicycle rental to generate income for the village community. The village officers still does not have the funds to provide bikes that will be rented to tourists or visitors. Other activities that can be done by tourists is seightseeing. There is one point that can be used as a stop over for tourists to enjoy the view of rice fields of Kendran Village. This point has not been managed properly, there is no facility that can be used for tourists yet.

b. Traditional house building

Like other tourist villages, Kenderan Village also offers traditional Balinese architecture building as one of its physical potential. The architecture of the traditional house will be maintained with a gate in front of the house as one of the hallmarks of Kendran Village.

c. Relics of history

The development of ancient tourism is a development of attractions where the discovery of ancient sites will become the object of tourist attraction. Based on field observations that have been done, there are some findings of ancient relics that have historical value that must be preserved and can be used as a tourist attraction. Some ancient relics that are found are nekara and twin sarcophagus.

An estimated nekara printing device is similar to the nekara found in Pejeng Village. Nekara in the belief of ancient society is a tool that has supernatural powers functioning as a tool of religious ceremony. Even the nekara found in the village of Pejeng in ancient times was considered the moon that fell from the sky. The invention of this nekara printing device shows that the nekara in Pejeng Village is the result of the local metal industry in ancient times that have advanced. So, this can be an excellence of historical attraction in the village of Kenderan. Until now this nekara printing equipment is then placed in the local temple.

Discovery of twin sarcophagus in community rice field area in which Sarcophagus is a collection of large stones arranged to resemble a chest used to store corpses in antiquity. Sarcophagus is the result of culture in the era of Megalithic, the great Stone Age. Because of its function to save corpses, the sarcophagus is also considered an object of spiritual power. The discovery of the twin sarcophagus is then stored in a temple called Pura Batu Lusu in the middle of rice fields of the village of Kenderan. Based on interviews with Mr. Eka Suparta regarding archaeological sites located in Kenderan Village, two sarcophagi found in the middle of the village rice field until now the exact origin can not be known. There are some researchers who have examined ancient findings in the village of Kenderan, but they also have not been able to estimate the exact age of the sarcophagus because when it was found both sarcophagi was empty.

\section{d. Holy places}

Like other villages, Kendran Village also has many shrines belonging to the local community. These holy places are like Pura Desa Adat Kenderan where nekara printing equipment is located in Kendran Village. Batu Lusu Temple is the one where the discovery of sarcophagus found in the middle of the rice fields of the community, Pura Griya Sakti Manuaba in Manuaba Village is worshipped by brahmana descendants, not only in the village but also outside the village. Not far 
from Pura Griya Sakti Manuaba there is a bath of Damakeling. It is said that this bath is a bath of The GodsGoddess of Pura Griya Sakti Manuaba. In addition there is also Pura Sira Mandari which is very unique. This temple is also a bath of the angels, and last but not least, this bath is located on the side of a cliff around which there is a cliff.

\section{B. Socio-Cultural Potential}

Kendran village has some socio-cultural potential that can be an attraction for tourists. It includes community life and religious ritual activities of Kendran Village. People starts their daily activities from going to the rice fields, growing rice, raising livestock, even traditional games, can be an interesting attraction when packaged properly.

In addition to community life, religious ceremonies are one of the socio-cultural potentials in Kendran Village. There are many holy days, so that people's lives are full of religious activities starting from preparing offrering, praying every full moon, tilem or kajeng kliwon, Galungan, Kuningan, Nyepi, or other big days.

There is one unique tradition that is done by villagers of Desa Pakraman Manuaba in every ceremony at Pura Giya Sakti Manuaba. This tradition is commonly known as Ngaturang Toya Ning tradition similarly done in other area. It is the activity of picking holy water up from village spring water prior to the ceremony. The uniqueness of this tradition is the process of delivering holy water to the temple of Griya sakti Manuaba. The holy water or the throne to be arranged is taken from the Damakeling bath which also serves as a beji from Pura Giya Sakti Manuaba.

\section{Potential of Village Community Creativity}

Wooden art craft and concreted art craft centers in Kendran village are geographically very strategic, located in the tourism route of Ubud Village, to the tourism object of Ceking (Tegalalang) and Kintamani. The potential is a very important factor for the development of wood craft and concrete art activities. Kendran village is a village that is located between crowded tourist villages such as Ubud Village, Tegalalang and Kintamani, having the opportunity to develop faster than the surrounding inland villages. The location of wooden art and crafted art centers leads to interactions that affect the development of products produced.

The existence of wood and concrete artworks in the midst of Kendran Village community was originally a side activity. Along with the growth of population and the development of the era, the business of wood craft and concrete art in the village of Kendran is one of the potentials developed.

The growth of wood craft and concrete art activities is the creativity of society in anticipating social and economic conditions. According to local crafters, this activity is a form of business to meet the needs of life for the community. Wood craft and concrete Art are the efforts, especially in Kendran Village community, which has involved almost all society. All daily activities are dominated and concentrated by making wooden art and concrete artwork as home industry activity.

According to local craftsmen, buyers or subscribers do not only buy finished goods but they also order by own models of goods or designs of various forms and functions. The entry of various models and new design brought by the buyer, has a lot to add the kind of treasury of wooden and concrete art products that can be adapted and done by craftsmen in Kendran Village.

The low level of education and the simplicity of mindset among craftsmen in their work and and business, endeavors to emphasize things that are practical, and as soon as possible to enjoy the results. The faster a business is profitable, the easier they are motivated to act and take advantage of the opportunity. Likewise, in the center of wood craft and concrete art in Kendran Village, the crafters, especially the chairman of the group or business owner, always know and aware of demand and good prospects. They perform creative and innovative actions with various forms of manifestation that are generally reflected in efforts to improve human resource skills, strengthen capital, continuity of raw material procurement, machinery of appropriate equipment, network expansion, improvement of business management structuring capabilities.

At this time everyday people of Kendran Village are always busy with economic activities, especially in the field of wood craft and concrete art. Parents, teenagers, and children who are either in school or after school hours are constantly preoccupied with economic activities in neighboring or self-owned business groups. They can choose work according to their interests and talents, from easy work to hard work, for example making sculptures until smoothing so that the goods are ready for sale.

The demands of the production process in the economic activities of making wooden and concrete artworks require a lot of manpower, especially when working on orders. Therefore almost all of the labours in Kendran Village are absorbed in the economic activity which is centered on making wooden and concrete artwork, with income between Rp 10,000 and Rp 100,000 per day.

\section{GRAND STRATEGY FOR DEVELOPING OBJECT AND ATTRACTIVENESS OF KENDERAN VILLAGE AS A CULTURAL TOURISM-BASED TOURISM VILLAGE}

Based on the analysis of the internal and external environmental factors of tourist objects and attractions of Kendran Village, the position of the internal environment of tourist objects and attractions of Kenderan Village is in the position of being with the value obtained 2531 and the position of the external environment of attractions and attractions Kenderan Village is in position 2531 with a value obtained 2.867. From both IFAS and EFAS matrices combined will result in a grand strategy of object development and tourist attraction that will be plotted into the Internal-External matrix of the Nine cell diagram, as shown in the following figure. 


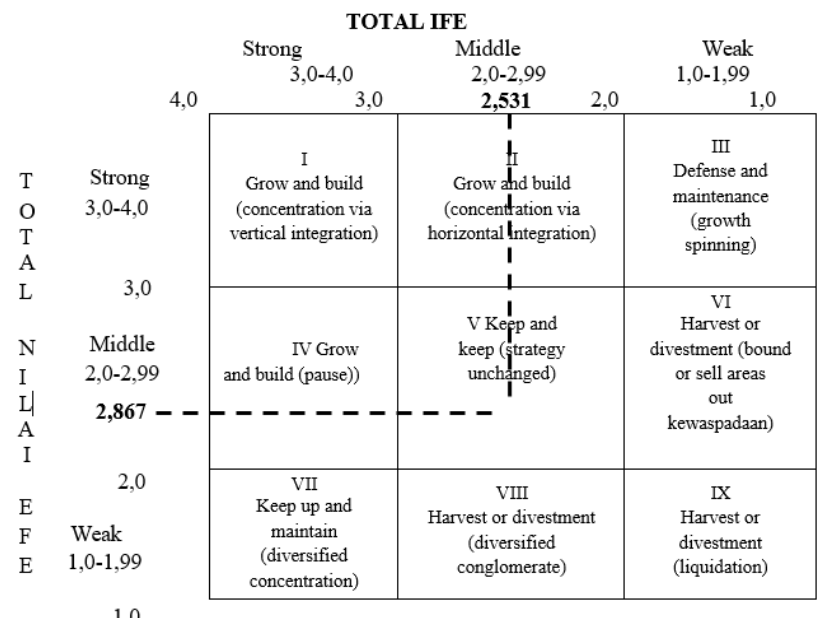

1,0

\section{SWOT ANALYSIS OBJECTS AND ATTRACTION OF KENDERAN VILLAGE AS A CREATIVE ECONOMY-BASED TOURIST VILLAGE}

Based on internal and external environmental factors of Kendran Village attractions SWOT analysis is an alternative strategy of object development and tourist attraction. SWOT matrix can generate four sets of alternative strategic possibilities of development in accordance with the potential and conditions of internal and external environment that belongs to the object and attractiveness of Kendran Village to be developed as a creative economy-based tourist village. From each strategy it can be elaborated or derived various development programs that support the objects and attractions of Kendran Village. The SWOT analysis matrix can be seen in Figure 5.2 below.

Based on the SWOT analysis matrix, then followed by QSPM analysis, it shows that sequence of strategies ranges from the most priority to least one. From the figure below, it shows that internal and external environmental factors of Kendran Village attraction result in four sets of possible alternative development strategies.

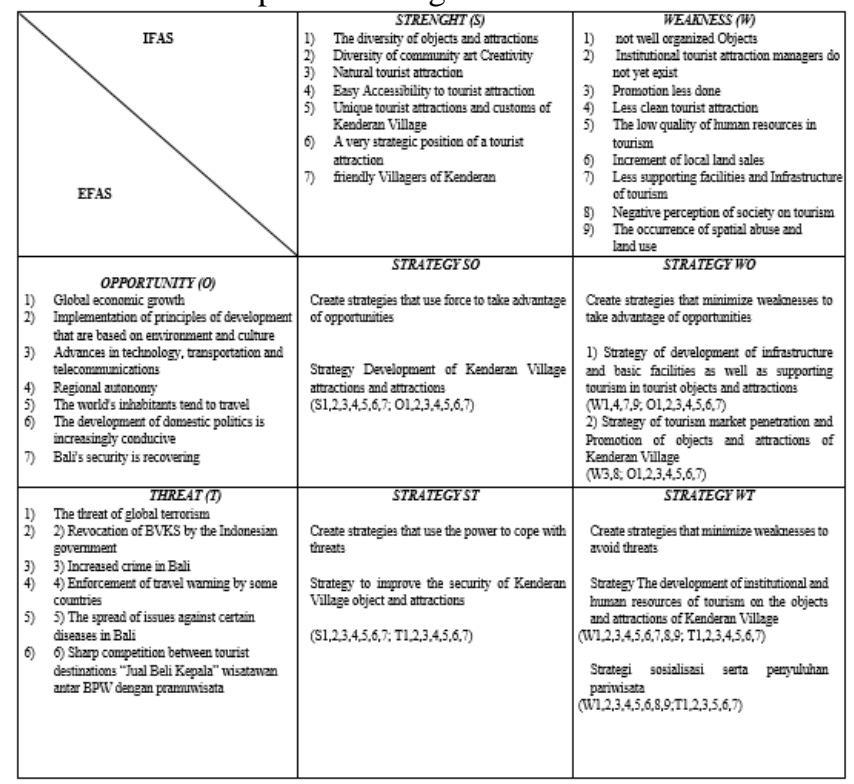

From each strategy, a variety of development programs that support the village of Kendran as a crerative economybased tourist village was made. Each strategies include:

SO Strategy

It is a strategy that uses the power to exploit opportunities, resulting in: the object development strategy and tourist attraction of Kendran Village (S1, 2, 3, 4, 5, 6, 7; O1, 2, 3, 4, 5, 6, 7) of which programs include:

a. Developing diversified tourism products

b. Maintaining the natural beauty and creativity of the art community

c. Maintaining the authenticity of the natural beauty ST Strategy

It is a strategy that uses the power to overcome threats, resulting in: a strategy to improve the security of Kendran Village objects and attractions (S1, 2, 3, 4, 5, 6, 7; T1, 2, 3, $4,5,6,7$ ) of which programs include:

a. Cooperating with the local police in maintaining environmental security

b. Improving security by involving the community. WO Strategy

Is a strategy that minimizes the weaknesses to take advantage of opportunities, resulting in: the development strategy of infrastructure and basic facilities as well as supporting tourism in the objects and attractions of the Kendran village (W1, 2, 3, 4, 5, 6, 7; O1, 2, 3, 4, 5, 6, 7) of which programs include:

a. Repairing road infrastructure and transportation facilities

b. Providing entrance gate

c. Providing eco-green accommodation

d. Providing restaurants

e. Providing rest room facilities or public bathrooms

f. Providing parking area

Penetration strategy to the tourism market and tourism object promotion at Kenderan Village (W3,8; O1,2,3,4,5,6,7) was made with such programs as:

a. Expanding market share

b. Conducting promotion through Travel Bureau

c. Promotion through hotel

d. Established TIC (Tourism Information Center)

e. Conducting promotion via internet

WT Strategy

Is a strategy that minimizes the weakness to avoid threats, resulting in: Strategy of institutional development and human resources of tourism on the object and tourist attraction of Kendran Village as a creative tourism village (W1, 2, 3, 4, 5, 6, 7, 8, 9; T1, 2, 3, 4, 5, 6, 7) and Strategy of socialization as well as tourism counseling (W1, 2, 3, 4, $5,6,8,9 ; \mathrm{T} 1,2,3,5,6,7)$ of which programs include:

Establishing a special institution that is responsible for managing the object and tourist attraction of Kendran Village to be a creative economy-based Tourist Village

Improving the quality of Human Resources (HR) to be able to manage potential of Kenderan Village

a. Cooperating with tourism education institutions

b. Conducting a counseling of tourism awareness 
c. Fostering and growing the home industry

\section{CONCLUSION}

Based on the results of the research in this first year, some conclusions might be drawn as follows:

a. The tourism potentials at Kendran Village are divided into three, namely the potential of natural tourism (landscape of rice fields), cultural tourism potential (socio-cultural life of the community, traditional Balinese architecture, historical relics of ancient findings, as well as local religious community), and creativity of local communities (tremendous potential in terms of sculpture both made of wood and of concrete).

b. The general strategy that must be implemented in developing the object and the tourist attraction of Kendran Village as a creative economy-based tourist village is an unchanging strategy, which maintains its own potential and develops innovation in order to maintain its sustainable potential.

\section{REFERENCES}

[1] O. Can-Seng, "Tourism and the Creative Economy in Singapore", 2009.

[2] Y. Oka, "Pengantar Ilmu Pariwisata", Angkasa, Bandung, 1985.

[3] Y. Ozen Kirant and I. Orhan, "A Model Proposal on the Use of Creative Tourism Experiences in Congress Tourism and the Congress Marketing Mix", 2010.

[4] Barringer and Bluedorn A. C., "The Relationship Between Corporate Entrepreneurship and Strategic Management", 1999.

[5] B. Barry and Joel R. Evans, "Retail Management: a Strategic Approach", New Jersey, 2009.

[6] I. Edward, "Tourism Planning and Sustainable Development Approach", Van Nostrand Reinblod. New York. 1991.

[7] R. Freddy, "Strategi Promosi yang Kreatif dan Analisa Kasus Integrated Marketing Communication", PT. Gramedia Pustaka Utama, Jakarta, 2009. 